\title{
Micronuclei and sialic acid as markers of genotoxic damage in tobacco-related oral lesions
}

\author{
Dahal S ${ }^{1}$, Boaz K ${ }^{2}$, Srikant N², Reshma K ${ }^{3}$, Agrawal N ${ }^{1}$ \\ ${ }^{I}$ Department of Dentistry, Tribhuvan University Teaching Hospital, Kathmandu, Nepal \\ ${ }^{2}$ Department of Oral Pathology and microbiology, Manipal College of Dental Sciences, Mangalore, India \\ ${ }^{3}$ Department of Biochemistry, Kasturba medical College, Mangalore, India
}

\section{Keywords:}

Free sialic acid; Micronuclei; Oral cancer; Premalignant; Protein bound sialic acid; Tobacco

\begin{abstract}
Background: Carcinogens and co-carcinogens act in an additive, synergistic and antagonistic manner. Tobacco is the most common carcinogen related to oral cancer. The aim of this study was to assess the effect of tobacco on the oral epithelium by evaluating genotoxic damage to cells as quantitated by micronuclei and also the alterations to the cell membrane were correlated by the measurement of free sialic acid and protein-bound sialic acid in saliva and in serum.

Materials and Methods: Blood samples collected from 15 untreated oral squamous cell carcinoma patients, 15 patients with oral precancerous conditions, 15 tobacco chewers without clinically evident lesion and 15 non-tobacco chewers. Serum and salivary sialic acid levels both in free and bound form were measured spectrophotometrically. Smear was taken from the same patient from the suspicious site and assessment of micronuclei was done by acridine orange method.

Results: Serum free sialic acid and micronuclei assessment showed greater level of significance $(\mathrm{P}=\leq 0.05)$ between all other groups. This implies it's potential use as an indicator of oral cancer. Predictability of occurrence of oral Cancer $=0.561+0.005 \times$ serum protein-bound sialic acid +0.244 serum free sialic acid $+0.71 \mathrm{M}$, where $\mathrm{M}=$ mean of micronuclei in 500 exfoliated oral cells. Predictability of occurrence of oral Premalignancy $=0.13+0.909 \times$ serum free sialic acid $+0.045 \mathrm{M}$, where $\mathrm{M}=$ mean of micronuclei in 500 exfoliated oral cells.
\end{abstract}

Conclusion: Micronuclei, serum and salivary sialic acid levels may be a good marker for prediction of premalignancy and oral squamous cell carcinoma transformation.

\section{INTRODUCTION}

Human population groups are exposed to a variety of carcinogens and co-carcinogens that can act in an additive, synergistic and antagonistic manner. ${ }^{1,2}$ Of the carcinogens tobacco is the most common carcinogen related to oral

\section{Correspondence:}

Dr. Samarika Dahal

Department of dentistry

Institute of Medicine, Maharajgunj, Kathmandu, Nepal cancer as it causes DNA damage or chromosome damage by direct contact and exposure to the oral epithelial cells.

Among the various tests available to measure genotoxic damage the micronucleus test has received increased attention as a sensitive biologic marker of genotoxic exposure. The micronucleus assay performed on human exfoliated cells may act as an indicator of a potential cancer developing in carcinogen-exposed tissues. ${ }^{3}$ 
Similarly, the measurement of serum and salivary glycoproteins and glycolipids has received a wide range of acceptance in screening of oral cancer. Any intracellular or micro-environmental change may lead to alteration in cell surface membrane constituents, releasing altered molecules in the blood and saliva of such patients. One such glycoprotein gaining acceptance as a serological marker for OSCC diagnosis is sialic acid.4 Recent studies have been directed towards the estimation of levels of Total Sialic Acid (TSA), Free Sialic Acid (FSA), Protein-bound Sialic Acid (PBSA) and Lipid-Associated Sialic Acid (LASA) in premalignant and malignant lesions. ${ }^{5,6}$

The present study was an attempt to correlate the FSA and PBSA levels in saliva and serum in groups of subjects with tobacco habit, some of whom may manifest oral premalignant lesions or oral cancer. The levels of sialic acid was also correlated with the micronuclei in exfoliated oral epithelial cells that act as direct markers of genotoxic damage.

\section{MATERIALS AND METHODS}

The study was undertaken in the Department of Oral Pathology and Microbiology, Manipal College of Dental Sciences, Mangalore with additional laboratory assistance from the Department of Biochemistry at Kasturba Medical College, Mangalore.

The study group consisted of 60 patients out of which 45 were males and 15 were females. The other demographic data and distribution of the study is given in Table 1 .

Only those patients were included in the study who consumed tobacco, cigarettes and smokeless tobacco. Patients with diabetes mellitus, pregnancy, liver cirrhosis, history of alcohol consumption, xerostomia, hypothyroidism/ hyperthyroidism, major depressive disorders, cardiovascular disease, ${ }^{7-13}$ therapeutic radiation, patients with oral tobaccorelated lesion in inaccessible areas of oral cavity or with tenderness that precluded ease and comfort of smear collection were excluded from the study.

The study comprised of four categories of patients divided into various groups.

Group I comprised of healthy individual without any tobacco habit, Group II were without clinically identifiable tobacco-related oral lesion, Group III Tobacco chewers with clinically identifiable tobacco-related oral lesion (leukoplakia and/or erythroplakia) and Group IV Oral Squamous Cell Carcinoma (Histologically-proven).

The common tobacco placement habit of the patient was identified by history and two smears were taken with wooden spatula and smeared on to the clean grease free clean glass slides which were then fixed in $95 \%$ ethyl alcohol and stained with $0.1 \%$ acridine orange. ${ }^{14,15}$ The number of micronuclei was assessed in 500 cells counted at 100x magnification (NA 1.25) using Leitz Aristoplan research microscope with fluorescence attachment. The identifying criteria used for micro-nucleation were according to Countryman and Heddle given as follows ${ }^{16}$ :

1. Resembles the nucleus of the cell but of smaller size

2. Round to ovoid with distinct outlines

3. Non-refractile and has the same colour as the main nucleus

4. Diameter less than $1 / 3$ of the main nucleus

5. To eliminate false positive count only cells exhibiting cytoplasmic boundaries were included in the count.

Blood samples and saliva were collected between 9.00 and 11.00 hours to avoid any possible diurnal variations. Sera

Table 1: Demographic data and distribution of the subjects in the study

\begin{tabular}{|c|c|c|c|c|}
\hline S No & Variable & Categories & No & Percentage \\
\hline \multirow[t]{4}{*}{1} & Groups & Group I= Controls & $15(\mathrm{M}=8, \mathrm{~F}=7)$ & 35.93 \\
\hline & & Group II= Tobacco chewers with no clinically identifiable oral lesion & $15(\mathrm{M}=8, \mathrm{~F}=7)$ & 35.93 \\
\hline & & Group III= Premalignant lesions $(\mathrm{PML})$ & $15(\mathrm{M}=13, \mathrm{~F}=2)$ & 51.26 \\
\hline & & Group IV= Oral squamous cell carcinoma (OSCC) & $15(\mathrm{M}=13, \mathrm{~F}=2)$ & 51.26 \\
\hline \multirow[t]{4}{*}{2} & Site & Tongue & 3 & 20 \\
\hline & & Floor of mouth & 1 & 6.66 \\
\hline & & Buccal mucosa & 10 & 6.66 \\
\hline & & Retromolar trigone & 1 & 6.66 \\
\hline 3 & $\begin{array}{l}\text { Histopathological } \\
\text { diagnosis }\end{array}$ & $\begin{array}{l}\text { (Well differentiated) } \\
\text { (Moderately differentiated) } \\
\text { (Poorly differentiated) }\end{array}$ & $\begin{array}{l}8 \\
6 \\
1\end{array}$ & $\begin{array}{c}53.3 \\
40 \\
6.66\end{array}$ \\
\hline 4 & TNM stage & $\begin{array}{l}\text { Stage I } \\
\text { Stage II } \\
\text { Stage III } \\
\text { Stage IV }\end{array}$ & $\begin{array}{l}3 \\
1 \\
4 \\
7\end{array}$ & $\begin{array}{c}20 \\
6.66 \\
26.6 \\
46.6\end{array}$ \\
\hline
\end{tabular}


Table 2: ANOVA test done for comparison of micronuclei between different groups of study subjects

\begin{tabular}{|c|c|c|c|c|c|c|c|}
\hline Micronuclei & $\mathbf{N}$ & Mean & $\begin{array}{l}\text { Micronuclei/ } \\
100 \text { cells }\end{array}$ & Std. Deviation & Std. Error & $\mathbf{F}$ & Sig. \\
\hline Controls & 15 & 0.73 & $0.14 \pm 0.17 \%$ & 0.88 & 0.22 & 24.15 & $<0.05$ \\
\hline Tobacco user & 15 & 1.66 & $0.33 \pm 0.19 \%$ & 0.97 & 0.25 & & \\
\hline $\begin{array}{l}\text { Premalignant } \\
\text { lesion }\end{array}$ & 15 & 2.40 & $0.48 \pm 0.18 \%$ & 0.91 & 0.23 & & \\
\hline Total & 60 & 2.15 & & 0.50 & 0.19 & & \\
\hline
\end{tabular}

Table 3: Kruskal Wallis test, Mann-Whitney U test and Bonferroni's correction test for determination of significant difference between the four groups in salivary and serum FSA and PBSA

\begin{tabular}{|c|c|c|c|c|c|c|c|}
\hline Catagory & $\mathbf{N}$ & $\operatorname{Min}(\mathrm{mg} / \mathrm{dl})$ & $\operatorname{Max}(m g / d l)$ & Media n & Chi Square & P Value & $\begin{array}{l}\text { Mann-Whitney U test and } \\
\text { Bonferroni's correction test) }\end{array}$ \\
\hline \multirow{4}{*}{ SalPBSA } & Control & 1.00 & 4.90 & 2.10 & \multirow{4}{*}{31.34} & \multirow{4}{*}{$<.0001$} & \multirow{4}{*}{$\begin{array}{c}\text { Control Vs Other } \\
+ \\
\text { Tobacco user Vs Oscc } \\
\mathrm{P}<0.001\end{array}$} \\
\hline & Tobacco user & 3.70 & 5.90 & 4.40 & & & \\
\hline & PML & 2.10 & 9.40 & 5.20 & & & \\
\hline & OSCC & 4.01 & 7.90 & 5.80 & & & \\
\hline \multirow{4}{*}{ SalFSA } & Control & 0.09 & 3.78 & 1.80 & \multirow{4}{*}{24.40} & \multirow{4}{*}{$<.0001$} & \multirow{4}{*}{$\begin{array}{c}\text { PML/OSCC Vs Control } \\
+ \\
+ \\
\text { PML/OSCC Vs tobacco } \\
\text { users } \\
\mathrm{P}<0.01\end{array}$} \\
\hline & Tobacco user & 1.40 & 4.80 & 2.10 & & & \\
\hline & PML & 2.23 & 4.80 & 3.70 & & & \\
\hline & OSCC & 2.30 & 5.81 & 3.81 & & & \\
\hline \multirow{4}{*}{ SerPBSA } & Control & 33.75 & 81.00 & 65.50 & \multirow{4}{*}{27.59} & \multirow{4}{*}{$<.0001$} & \multirow{4}{*}{$\begin{array}{c}\text { OSCC Vs ( Control / tobacco } \\
\text { users/ PML) }\end{array}$} \\
\hline & Tobacco user & 42.00 & 97.00 & 65.50 & & & \\
\hline & PML & 43.40 & 97.70 & 72.10 & & & \\
\hline & OSCC & 76.00 & 230.20 & 110 & & & \\
\hline \multirow{4}{*}{ SerFSA } & Control & 0.03 & 0.17 & 0.10 & \multirow{4}{*}{49.45} & \multirow{4}{*}{$<.0001$} & \multirow{4}{*}{$\begin{array}{c}\text { All except Control Vs tobacco } \\
\text { user } \\
\mathrm{P}<0.001\end{array}$} \\
\hline & Tobacco user & 0.04 & 0.86 & 0.06 & & & \\
\hline & PML & 1.03 & 1.18 & 1.10 & & & \\
\hline & OSCC & 1.08 & 1.42 & 1.32 & & & \\
\hline
\end{tabular}

Sal $=$ Saliva $;$ Ser $=$ Serum

were separated and stored at $-20^{\circ} \mathrm{C}$ until analysed.

Stock solution of NANA of $0.5 \mathrm{mg} / \mathrm{ml}$ and acidic ninhydrin reagent II were prepared according to Gaitonde $1967 .{ }^{17}$

\section{Assays}

Estimation of PBSA in serum and saliva, FSA in saliva were analysed using the method of Yao et al method. ${ }^{18,19}$ Estimation of FSA levels were analysed using the method of Skoza and Mohos. ${ }^{10}$

Serum and salivary levels were compared between four groups using Kruskal Wallis test which showed significant difference in FSA and PBSA levels both in serum and saliva.

\section{Statistical Analysis}

Anova test was done for the evaluation of variation in micronuclei between different categories of patient. Turkey's post hoc test was done for the evaluation of the most significant group of patient showing variation in micronuclei.

Kruskal Wallis test was done for the comparison of Serum and salivary levels of sialic acid between the four groups of patient taken in the study. 
Table 4: Comparison to evaluate difference of significance in salivary and serum sialic acid among all the groups in the study

\begin{tabular}{|c|c|c|c|c|c|}
\hline S no & Comparison groups & SalPBSA & SalFSA & SerPBSA & SerFSA \\
\hline \multirow{2}{*}{1.} & Control & \multirow{2}{*}{$\checkmark$} & \multirow{2}{*}{$x$} & \multirow{2}{*}{$x$} & \multirow{2}{*}{$x$} \\
\hline & Tobacco user & & & & \\
\hline \multirow[t]{2}{*}{2.} & Control & \multirow{2}{*}{$\checkmark$} & \multirow{2}{*}{$\checkmark$} & \multirow{2}{*}{$x$} & \multirow{2}{*}{$\checkmark$} \\
\hline & PML & & & & \\
\hline \multirow{2}{*}{3.} & Control & \multirow[b]{2}{*}{$\checkmark$} & \multirow[b]{2}{*}{$\checkmark$} & \multirow[b]{2}{*}{$\checkmark$} & \multirow[b]{2}{*}{$\checkmark$} \\
\hline & OSCC & & & & \\
\hline \multirow{3}{*}{4.} & Tobacco user & \multirow{3}{*}{$x$} & \multirow{3}{*}{$\checkmark$} & \multirow{3}{*}{$x$} & \multirow{3}{*}{$\checkmark$} \\
\hline & & & & & \\
\hline & PML & & & & \\
\hline \multirow{2}{*}{5.} & Tobacco user & \multirow{2}{*}{$\checkmark$} & \multirow{2}{*}{$\checkmark$} & \multirow{2}{*}{$\checkmark$} & \multirow{2}{*}{$\checkmark$} \\
\hline & OSCC & & & & \\
\hline \multirow{2}{*}{6.} & PML & \multirow{2}{*}{$x$} & \multirow{2}{*}{$x$} & \multirow{2}{*}{$\checkmark$} & \multirow{2}{*}{$\checkmark$} \\
\hline & OSCC & & & & \\
\hline
\end{tabular}

Sal $=$ Saliva; Ser $=$ Serum

Table 5: Forward step-wise regression done for correlation of serum sialic acid with micronuclei of cases with oral cancer Vs other groups and premalignant lesion Vs controls

\begin{tabular}{|c|c|c|c|c|c|c|c|c|}
\hline \multirow{2}{*}{$\begin{array}{l}\text { Outcome } \\
\text { compared }\end{array}$} & \multirow{2}{*}{ Mode } & \multirow{2}{*}{ Test used } & \multicolumn{2}{|c|}{ Unstandardized coefficients } & \multirow{2}{*}{$\begin{array}{c}\text { Standardized } \\
\text { Coefficients } \\
\text { Beta }\end{array}$} & \multirow{2}{*}{$\mathrm{t}$} & \multirow{2}{*}{ Sig. } & \multirow{2}{*}{ Formula } \\
\hline & & & Beta & Std. Error & & & & \\
\hline \multirow{3}{*}{ 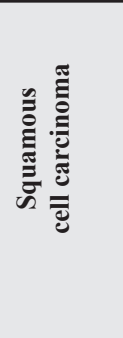 } & 1 & $\begin{array}{l}\text { (Constant) } \\
\text { SerPBSA }\end{array}$ & $\begin{array}{c}0.58 \\
0.008\end{array}$ & $\begin{array}{c}0.10 \\
0.001\end{array}$ & 0.66 & $\begin{array}{l}5.49 \\
6.82\end{array}$ & $\begin{array}{l}<0.05 \\
<0.05\end{array}$ & \multirow{3}{*}{$\begin{array}{l}\text { Oral cancer }=0.561+0.005 \mathrm{x} \\
\text { serum PBSA }+0.244 \text { serum } \\
\text { FSA }+0.71 \mathrm{M}\end{array}$} \\
\hline & 2 & $\begin{array}{l}\text { (Constant) } \\
\text { SerPBSA } \\
\text { SerFSA }\end{array}$ & $\begin{array}{c}0.58 \\
0.005 \\
0.33\end{array}$ & $\begin{array}{c}0.09 \\
0.001 \\
0.07\end{array}$ & $\begin{array}{l}0.44 \\
0.43\end{array}$ & $\begin{array}{l}6.31 \\
4.42 \\
4.32\end{array}$ & $\begin{array}{l}<0.05 \\
<0.05 \\
<0.05\end{array}$ & \\
\hline & 3 & $\begin{array}{l}\text { (Constant) } \\
\text { SerPBSA } \\
\text { SerFSA } \\
\text { Micronuclei }\end{array}$ & $\begin{array}{c}0.56 \\
0.005 \\
0.24 \\
0.07\end{array}$ & $\begin{array}{c}0.09 \\
0.001 \\
0.08 \\
0.03\end{array}$ & $\begin{array}{l}0.37 \\
0.31 \\
0.24\end{array}$ & $\begin{array}{l}6.17 \\
3.71 \\
2.83 \\
2.21\end{array}$ & $\begin{array}{l}<0.05 \\
<0.05 \\
0.006 \\
0.031\end{array}$ & \\
\hline \multirow{2}{*}{ 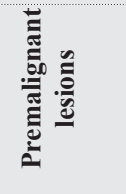 } & 1 & $\begin{array}{l}\text { (Constant) } \\
\text { SerFSA }\end{array}$ & $\begin{array}{c}-0.08 \\
0.95\end{array}$ & $\begin{array}{l}0.02 \\
0.03\end{array}$ & 0.96 & $\begin{array}{l}-3.58 \\
25.42\end{array}$ & $\begin{array}{l}0.001 \\
<0.05\end{array}$ & \multirow{2}{*}{$\begin{array}{l}\text { Oral Premalignancy = } \\
0.13+0.909 \mathrm{x} \text { serum FSA } \\
+0.045 \mathrm{M}\end{array}$} \\
\hline & 2 & $\begin{array}{l}\text { (Constant) } \\
\text { SerFSA } \\
\text { Micronuclei }\end{array}$ & $\begin{array}{c}-0.13 \\
0.90 \\
0.04\end{array}$ & $\begin{array}{l}0.03 \\
0.03 \\
0.17\end{array}$ & $\begin{array}{l}0.92 \\
0.10\end{array}$ & $\begin{array}{r}-4.66 \\
23.40 \\
2.69\end{array}$ & $\begin{array}{l}<0.05 \\
<0.05 \\
0.010\end{array}$ & \\
\hline
\end{tabular}

Ser $=$ Serum

Post hoc analysis by Bonferroni's correction test was done for the determination of significant difference between the four groups in salivary and serum FSA and PBSA

To identify the best prognosticators, Forward step-wise regression analysis was done combining all the parameters.

\section{RESULTS}

In the study significant differences in no of micronuclei between the categories were seen as shown by ANOVA $(\mathrm{F}=24.15, \mathrm{P}=<0.05)$. Maximum $\mathrm{MN}$ was seen in OSCC patients with mean and standard deviation of $3.80 \pm 1.26$. Turkey's post hoc test showed the difference was mainly between OSCC and other groups and PML and controls (Table 2).

In the study significant difference in serum and salivary levels of sialic acid between the categories were seen as shown by Kruskal Wallis test $(\mathrm{P}=<.0001$; Table 3$)$. Post hoc analysis by Bonferroni's correction test showed the Variation between PML and OSCC was indicated by serum PBSA and serum FSA, Salivary FSA and PBSA was significantly varied in controls and PML (Table 4). This 
indicates that the serum SA levels are increased in OSCC and Sal SA levels increases in PMC.

Among all the assessment of sialic acid levels and micronuclei counts performed in the present study, serum FSA and micronuclei assessment showed greater level of significance $(\mathrm{P}=<0.05)$ between all other groups. Forward step-wise regression analysis showed that combination of micronuclei and sialic acid levels can be used as a predictor of premalignancy and malignancy. This implies it's potential use as an indicator of oral cancer. Predictability of occurrence of oral cancer $=0.561+0.005 \times$ serum PBSA + 0.244 serum FSA $+0.71 \mathrm{M}$, where $\mathrm{M}=$ mean of micronuclei in 500 exfoliated oral cells. Predictability of occurrence of oral Premalignancy $=0.13+0.909 \times$ serum FSA $+0.045 \mathrm{M}$, where $\mathrm{M}=$ mean of micronuclei in 500 exfoliated oral cells (Table 5).

\section{DISCUSSION}

Oral squamous cell carcinoma is the most common form of oral cancer and has high mortality and morbidity rates. The most essential diagnostic challenge would be to detect the cancer earlier than the observable changes in the mucosa. This could be achieved by detecting damage to DNA at a very early stage. The effects of carcinogens on cellular material are measured as genotoxicity, which quantitates the potential of a particular environment (chemical/electromagnetic) to cause damage to the DNA of a cell. A current method for detecting DNA damage includes the measurement of levels of genotoxic chemicals, their metabolites and derivatives in body fluids. The biochemical tests for oral cancer would include detection of all carcinogenic agents present in the tobacco like Benzo[a]pyrene, ethylcarbamate, volatile aldehydes, nitrosamines and nitrosamino acids. A direct technique such as chromatin staining would measure biological responses as cytogenetic changes in exposed individuals. Flow cytometry can also be used for the assessment but is technique sensitive and requires specific equipment. On the other hand, the evaluation of micronuclei by exfoliative cytology is an economical, feasible and noninvasive method of detection of genotoxic damage.

Assessment of micronuclei has been a marker for genotoxic damage in assessment of nuclear changes in tobacco users as well as in development of premalignancies as shown in studies by Kayal et al. ${ }^{20}$ Suhas et al. ${ }^{21}$ Halder et al. ${ }^{22}$ Kamboj and Mahajan, ${ }^{23}$ Sellappa et al. ${ }^{24}$

The present study showed a significant increase in number of micronuclei from healthy state to premalignancy to malignancy and reflects the findings of studies by Halder A et al. $^{22}$ and Kamboj et al. ${ }^{23}$ However, in the present study there was no significant correlation between tobacco usage (frequency and duration) and the frequency of micronucleated oral mucosal cells which is contrary to the findings by Kayal et al. ${ }^{20}$ Halder et al. ${ }^{22}$ Kamboj et al. ${ }^{23}$
Gabriel et al. ${ }^{3}$ Palve et al. ${ }^{15}$

This questions the premise of cancer developing irrespective of genotoxic etiology. Presently, many cancers are seen to occur in the absence of a history of harmful habits while environmental pollution exposes people to carcinogens more frequently. There is no unequivocal evidence pointing to the occurrence of micronuclei as being produced by tobacco-related agents or due to genetic progression of normal state to premalignant state to malignant lesions. Though micronuclei are a marker of genotoxic damage indicating transformation of normal mucosa to premalignant lesion, and subsequently malignancy, they may be present irrespective of the tobacco usage as reported by Yildirim et al. ${ }^{25}$ and Armen et al. ${ }^{26}$ in whose studies even those without habits developed carcinoma and showed increase in number of micronuclei. We thus speculate that micronuclei and not the history of the habit may be a reliable factor in quantification of genotoxic damage to nuclei and DNA.

Carcinogens not only alter nuclear material but also the other structures of cell such as cytoplasmic cell membrane molecules giving abnormal by-products. One such molecule which increases with progression of tumour is sialic acid which has 43 detectable types of which NANA (N-acetyl nuraminic acid) is routinely assessed and has been evaluated in the present study. Assessment of total serum/ salivary sialic acid is an effective tool to predict development of precancer and cancer as the sialic acid spills into circulation/ saliva.

Our study showed that there is an increase in the both salivary and serum sialic acid levels in the free state as well as in protein-bound state from precancer to cancer and supports the same trend observed in the studies by Baxi et al. ${ }^{4}$ Patel. ${ }^{27}$ Raval et al. ${ }^{28}$ Rajpura et al. ${ }^{29}$ Stoyloff J et al. ${ }^{30}$ Sanjay PR et al. ${ }^{31}$ This can be explained by the fact that there are alterations in cellular mechanisms pertaining to glycosylation seen during the oncogenesis. Glycosylation of proteins occur in the endoplasmic reticulum and Golgi compartments of the cell which involves a complex series of reactions catalysed by various membranebound glycosyltransferases. Dell and Morris stated that in malignancy, the glycosyltransferases are mutated producing abnormal glycoconjugates that have an increase in size of oligosaccharides resulting in more branching sites for incorporation of sialic acid. Immunohistochemistry and In-situ Hybridisation techniques suggest that sialylation is dominant in tumour cells and the extent of sialylation of the glycoconjugates can be determined by examining sialyltransferase activities. ${ }^{28}$ Glycosyltransferases also alter the cell surface glycoproteins giving sialyltransferase. ${ }^{32}$ Increased plasma sialyltransferase has also been observed in patients with cancers of head and neck, lung, colon, breast and also in lymphoma, malignant melanoma, adenocarcinoma, Hodgkin's disease etc. ${ }^{28}$ 
In the present study we observed a specific trend of sialic acid variation. In premalignant states, there was an increase in salivary free and protein-bound sialic acid levels, but with the development of malignancy, serum free sialic acid was increased first to be followed by increased levels of serum protein-bound sialic acid (Table 4). This could be explained by the carcinogenic action of tobacco on oral epithelium. Epithelial exposure to tobacco leads to genotoxic damage in premalignant lesions where the alterations to glycoconjugates are less severe resulting in the detection of sialic acid only in saliva. It is possible that as the degree of premalignancy increases with increasing exposure to carcinogens, the salivary protein-bound sialic acid gets converted into free form. Therefore, the overload of PBSA spills into saliva as FSA which then diffuses into blood with progression of malignancy. Thereafter, increasing duration and higher grades of carcinoma result in serum FSA converting to the protein-bound form of sialic acid. Sialic acid has been proven to be an efficient tool to assess tumour burden in which the size and duration of the tumour influences the salivary sialic acid as seen in our study.

Sialic acid may be an effective tool to predict lymph node involvement and metastasis also. This is attributed to spillage of the sialic acid directly into circulation by the metastasized tumour islands..$^{30}$ Iptonma et al. ${ }^{33}$ Harvey et al. ${ }^{34}$ Baxi et al. ${ }^{4}$ Patel et al. ${ }^{27}$ and Raval G..${ }^{35}$ have found that sialic acid levels increases progressively with metastasis of oral squamous cell carcinoma. Increasing levels of sialic acid causes decreased cell adhesion due to repulsive effects of the negatively-charged sialic acid causing increased cell mobility and lack of cohesion. ${ }^{35}$ Certain sialated mucinproducing tumour cells which spill into circulation are known to be resistant to clearance by liver receptors thus indicating that the antigenicity of a tumour cell decreases because of the abnormal glycosylation. These tumour cells coated with increased sialic acid recruit plasma factor $\mathrm{H}$ to its membrane thus efficiently evading the alternative pathway of complement activation. The above factors make it difficult for the tumour to be detected by the host. Thus, quantitating sialic acid could be an efficient tool to detect decreased cell adhesion reflected in tumour metastasis.

\section{CONCLUSION}

The present study sumerises that salivary and serum sialic acid can be used as markers for development of oral cancer. Out of which oral cancer can be best predicted using Serum PBSA and micronuclei assessment by using the formula Cancer $(\mathrm{Gp} 1)=0.561+0.005 \times$ serum PBSA +0.244 serum $\mathrm{FSA}+0.71 \mathrm{M}$. While oral premalignancy can be predicted by serum FSA by using the formula, PML $(\mathrm{Gp} 2)=0.13+$ $0.909 \times$ serum FSA+ $0.045 \mathrm{M}$.

\section{REFERENCES}

1. Sivasankari P, Kaur S, Reddy V, Rao R. Micronucleus index: an early diagnosis in oral carcinoma. J Anat Soc India 2008;57:8-13.

2. Nair U, Oberl G, Nair $J$ et al. Evaluation of frequency of micronucleated oral mucosa cells as a marker for genotoxic damage in chewers of betel quid with or without tobacco. Mutat Res 1991;261:163-68

3. Gabriel H, Crott J, Ghandour H et al. Chronic cigarette smoking is associated with diminished folate status, altered folate form distribution, and increased genetic damage in the buccal mucosa of healthy adults. Am J Clin Nutr 2006;83:835-41.

4. Baxi B, Patel P, Adhvaryu S. A report on clinical importance of serum glycoconjugates in oral cancer. Indian J Clin Biochem 1990;5:13944.

5. Tewaranson L, Mittal P, Singh M, Gupta P. Serum sialic acid - an important cancer marker. Indian J Cancer 1993;30:125-131.

6. Shetty P, Pattabiraman N. Salivary glycoproteins as indicators of oral diseases. Indian J Clin Biochem 2004;19:97-101.

7. Khurshid M, Munir N. Total serum sialic acid (TSSA) in selective patients of Diabetes Mellitus (DM). Annals 2008;14:46-49.

8. Khadapkar K, Sheth N, Bhide S. Independence of sialic acid levels in normal and malignant growth. Cancer Res 1975;35:1520-3.

9. Arif S, Haq N, Hanif R, A, Khan S, Rehman J, Mufti TA. Variations of serum sialic acid level in liver cirrhosis J Ayub Med Coll Abbottabad 2005; 17:54-7.

10. Chrostek L, Cylwik B, Krawiec A, Korcz W, Maciej S. Relationship between serum sialic acid and sialylated glycoproteins in alcoholics. Alcohol Alcohol 2007;42:588-92.

11. Kucharz E, Olczyk K, Glowacki A, Kassem M. Serum glycoproteins in patients with hypo and hyperthyroidism. Acta Biochimica Polonica 1993;40:151-3.

12. Nandave M, Ojha S, Kaur K. Changes in levels of serum glycoproteins in major depressive disorders. Indian J Clin Biochem 2005;20:154-7.

13. Rahman I, Malik S, Khan W. Relation of serum sialic acid with serum lipids in cardiac patients. Pak J Pharm Sci 2005;18:71.

14. Sandler H. The cytological diagnosis of tumours of the oral cavity. Acta Cytol 1964;8:114-20.

15. Palve D, Tupkari J. Clinico-pathological correlation of micronuclei in oral squamous cell carcinoma by exfoliative cytology. J Oral Maxillofac Pathol 2008;12:2-7.

16. Countryman PI, Heddle JA. The production of micronuclei from chromosome aberrations in irradiated cultures of human lymphocytes. Mutat Res 1976;41:321-32.

17. Gaitonde MK. A spectrophotometric method for the direct determination of cysteine in the presence of other naturally occurring amino acids. Biochem J 1967;104:627-33.

18. Yao K, Ubuka T, Masuoka N, Kinuta, Ikeda T. Direct determination of bound sialic acid in sialoglycoproteins by acidic Ninhydrin reaction. Analytical Biochem 1989;179:332-5.

19. Yao K, Ubuka T. Determination of sialic acids by acidic ninhydrin reaction. Acta Med Okayama 1987; 41:237-41.

20. Kayal JJ, Trivedi B, Nair J, Bhide V, Goswami C, Adhvaryu G Incidence of micronuclei in oral mucosa of users of tobacco products singly or in various combinations. Mutagenesis 1993; 8:31-3.

21. Suhas S, Ganapathy K, C. Ramesh. Application of the micronucleus test to exfoliated epithelial cells from the oral cavity of beedi smokers, a high-risk group for oral cancer. Mutat Res 2004;561:15-21.

22. Halder A, Chakraborty G, Das P, Raychowdhury S, Ghosh A Comparitive study of exfoliated oral mucous cells micronuclei frequency in normal precancerous and malignant epithelium. Int $\mathrm{J}$ Hum Genet 2004;4:257-60. 
23. Kamboj M, Mahajan S. Micronucleus-an upcoming marker of genotoxic damage. Clin Oral Invest 2006:58:225-8.

24. Sellappa S, Balakrishnan M, Raman S, Palanisamy S. Induction of micronuclei in buccal mucosa on chewing a mixture of betel leaf, areca nut and tobacco. J Oral Sci 2009;51:289-92.

25. Yildirim IH, Yesilada E, Yologlu S. Micronucleus frequency in peripheral blood lymphocytes and exfoliated buccal cells of untreated cancer patients. Russ J Genet 2006;42:573-7.

26. Nersesyan Armen K, Vardazaryan NS, Gevorgyan AL, Arutyunyan RM. Micronucleus level in exfoliated buccal mucosa cells of cancer patients. Archives of Oncology 2002;10:35-6.

27. Patel PS. Importance of glycoproteins in human cancer. Indian J Biochem Biophys 1997;34:226-33.

28. Raval GN, Patel DD, Parekh LJ, Patel JB, Shah MH, Patel PS. Evaluation of serum sialic acid, sialyltransferase and sialoproteins in oral cavity cancer. Oral Dis 2003;9:119-28.

29. Rajpura KB, Patel PS, Chawda JG, Shah RM. Clinical significance of total and lipid bound sialic acid levels in oral pre cancerous conditions and oral cancer. J Oral Pathol Med 2005;34:263-7.
30. Stoyloff J, Ivanov SX. Evaluation of sialic acids as tumour markers in thyroid, head and neck and lung tumours. Acad Bulg Sci 2005;8:2532 .

31. PR Sanjay, Hallikeri K, Shivashankara AR. Evaluation of salivary sialic acid, total protein, and total sugar in oral cancer: a preliminary report. Indian J Dent Res 2008;19:288-91.

32. Raval G, Parekh L, Patel D, Jha F, Sainger R, Patel P. Clinical usefulness of alterations in sialic acid, sialyltransferase and sialoproteins in breast cancer. Indian J Clin Biochem 2004;19):60-71.

33. Lipton A, Harvey HA, Delong S et al. Glycoproteins and human cancer circulating levels in cancer serum. Cancer 1979;43:1766-71.

34. Harvey HA, Lipton A, White D, Davidson E. Glycoproteins and human cancer: II Correlation between circulating level and disease status. Cancer 1981;47:324-27.

35. Stoyloff J, Ivanov SX. Evaluation of sialic acids as tumour markers in tumours of non-epithelial origin. Pathol Parasitol 2005;8;33-9. 